\title{
Image Annotation Statement
}

National Cancer Institute

\section{Source}

National Cancer Institute. Image Annotation Statement. NCI Thesaurus. Code C101135.

A statement used to describe something found and to be addressed on an image or series of images. It describes a thing found, measured and graphically annotated on an image or images from the same series. It consists of a subject, predicate and object. 